\title{
SHOULD WORKERS BE COMPELLED TO CONTRIBUTE?
}

\author{
GroRge H. Trafton*
}

In the country-wide movement for unemployment compensation or insurancenow given added impetus in the Federal Social Security Act-one of the principal controversial issues is whether or not the wage-earner should be required to make contributions to the reserve funds from which unemployment benefits are to be paid. With ten unemployment compensation laws already enacted, this important question of social policy has yet to receive a decisive legislative answer. ${ }^{1}$

Five states-Massachusetts and New Hampshire in New England, Alabama in the South, and California and Washington on the West Coast-have adopted systems that compel the worker to contribute. On the other hand, New York, with the largest industrial population of any state; Congress, acting for the District of Columbia; Wisconsin, in its pioneer American unemployment compensation law; and Oregon and Utah, representing the West, have enacted measures which require no employee contributions. Within the next few months, other states will find it necessary to choose which of these examples they will follow-with far-reaching consequences to their wage-earners and to social insurance in America.

In enacting America's first unemployment compensation law in I932, after ten years of consideration by its legislature, the progressive State of Wisconsin adopted the principle that the cost of unemployment compensation, like the cost of workmen's accident compensation, should be made an expense of doing business, with employers alone contributing. At the same time, through the device of establishment accounts in the reserve fund, employers were afforded the greatest possible opportunity to reduce, or even eliminate, this cost through efficient management in providing steady work. This plan has been recognized as a distinctively American approach to unemployment insurance.

The basic provisions of the Wisconsin act were immediately and vigorously attacked, not only by conservative employers who sought to prevent the adoption of such legislation by other states, but also by certain proponents of social insurance

- A.B., I924, Dartmouth College; three years of graduate study in labor economics, University of Wisconsin. Since 1929, research assistant, American Association for Labor Legislation, and associate editor, American Labor Legislation Review.

${ }^{1}$ The Federal Social Security Act, while levying a 3 per cent tax on employers, leaves the states free to enact laws with or without employce contributions. 
who favor the British scheme of three-way contributions-from employers, workers, and the state. Because fiscal difficulties have made the placing of additional burdens on the taxpayer appear politically impossible, most of these advocates have been willing as a practical matter to abandon the principle of state contributions; but many of them have continued to insist that wage-earners be compelled to contribute. ${ }^{2}$

Compulsory worker contributions have been insisted upon by many employers because they believe such a scheme will reduce the cost to themselves. The idea of worker contributions also appeals to the popular view that those who will benefit should be willing to pay at least part of the cost. Then too, it is thought by many that contributing to the unemployment reserve funds will maintain the workers' self-respect and remove the taint of "the dole." These views have been so widely expressed that, for a time, proponents of unemployment insurance who favored compulsory worker contributions argued that bills not requiring such contributions had little or no chance of enactment-outside of Wisconsin! This, events have since disproved.

A somewhat more refined argument sets forth the theory that workers who are required to contribute to the insurance funds will as a result take a strong interest in safeguarding these reserves against the malingering of fellow-workers. It is further contended that employees, by contributing, will gain the right to participate in administering the funds. The additional suggestion is made that if, as some theoretical economists have warned, the worker will in any event pay part or all of the cost of benefits through higher prices and lower wages, he might as well contribute directly and get the credit for doing so. Some advocates, however, have asserted that the really basic reason for worker contributions is that they are necessary in order to provide sufficient funds for adequate benefits.

Evidently, the controversy over compulsory worker contributions in unemployment compensation revolves around three basic issues: (I) The demands of justice in the distribution of the cost of unemployment benefits; (2) the effect of contributions upon employers and employees in their relation to the system; and (3) the question of adequate benefits.

Those who urge that it is only just to require wage-earners to pay part of the cost of unemployment benefits tend to overlook the fact that even under unemployment insurance, workers will continue to bear the major share of the burden of unemployment. Before benefits begin, the unemployed wage-earner must meet the entire cost for a waiting period usually of three weeks, but in some laws four or even six. Even when benefits are paid, they will amount to only a fraction of full wages, as a rule not more than $5^{\circ}$ per cent; and they are further restricted by a maximum, usually $\$ r_{5}$. These benefits, moreover, will continue for not more than a limited

\footnotetext{
${ }^{3}$ A leader in advocating compulsory worker contributions was the Ohio Commission on Unemployment Insurance whose "Ohio Plan" was widely used as a model by proponents of such contributions. In 1935, however, this feature was dropped after further consideration and the bill was passed by the Ohio House on January $16,1936$.
} 
number of weeks, in most instances sixteen, after which the entire cost will again fall upon the worker. Under a system of compensation which leaves the worker to sustain so large a share of the cost of unemployment, it is difficult to understand why on grounds of justice industry should not be required to pay the entire cost of unemployment benefits.

There is weight in the views of organized labor in this connection, as expressed - by William Green, President of the American Federation of Labor: ${ }^{3}$

"Labor is not responsible for unemployment. Workers are not in a position to control the causes of unemployment. That is a function of management. Unemployment compensation is a recognition of this fact. Simple justice demands that workers shall not be forced out of their inadequate earnings to pay for management's failure to stabilize employment. . . . Under our accident compensation laws we have rightly agreed that the worker should not have to contribute to the fund from which cash benefits are paid. As a cost of production, the insurance premium very properly is figured by the employer as a part of his over-head expense and is ultimately passed on to the consumer. The same arguments apply with special force against compelling the worker to contribute under unemployment compensation or insurance.

"Those who would force workers to contribute to unemployment insurance ignore the fact that while the employer is in a position to pass his contribution on to the consumer, workers can not do so. The worker therefore would bear the entire burden of such a levy; but the employer would escape. To argue that under a scheme of forced worker contributions workers will 'share' the cost with employers is to be guilty of deception. The worker would have to take his contribution out of his standard of living, but the employer can recoup his 'share' by slightly increasing the price of his product."

Proponents of employee contributions, especially those who continue to favor a state contribution, have sometimes involved themselves in strange inconsistencies when discussing the tendency of employer contributions to be reflected in the price of commodities. They argue that this will mean that workers will after all pay the employers' contribution; that it will in effect be a kind of "sales tax." If it appears unjust for workers to help pay for unemployment benefits through higher prices, the question is raised why these same advocates of three-way contributions so strongly favor making the wage-earner pay twice-by a deduction from wages as well as in higher prices. Labor has made its own position clear on this point. The stand taken by the American Federation of Labor since I932 is that "the whole should be paid by management as a cost of production."

The theory that worker contributions will tend to give wage-earners a more desirable attitude toward the unemployment compensation system is subject to proof only by the test of experience. It is probably significant that nothing in American experience under workmen's accident compensation justifies the belief that a social insurance system requiring no worker contribution will be taken as a dole by its beneficiaries. If available evidence proves anything, it is that legislation creating a

\footnotetext{
s Green, Why Labor Opposes Forced Worker Contributions in Job Insurance (I934) 24 AM. LAB. LEG. REV., I0I-I05.
} 
legal right to fixed cash payments lacks the essential element of "the dole," the grant of which is determined by a needs test; and that this difference is readily appreciated by the recipients, whether they be wage-earners, old folks, or war veterans.

The right of labor to an active interest in the provisions and administration of workmen's compensation legislation has not been seriously questioned, and the representatives of labor have never hesitated to assert that right. The fact that workers are not required to contribute apparently has cast not the least shadow of a doubt over the propriety of labor's making its voice heard in a legislative program so vitally affecting its welfare. That this same right should be in any way compromised by failure to contribute to an unemployment compensation system is hard to imagine. That it is not endangered in practice has already been demonstrated during the four years of experience with such legislation in Wisconsin, as well as under the New York and other more recent laws.

The belief that a compulsory contribution will increase the worker's concern for the protection of the reserve funds has also been challenged. The contributory system in England did not prevent British labor from asking for and obtaining an extension of benefits to unemployed workers who had not "earned" them. It is probable that the desired attitude on the part of labor may be assured, not by compelling workers to contribute, but by making it perfectly evident that the funds available for benefits are definitely limited in amount. If the workers understand that it is possible for the fund to be exhausted, they may be expected to protect its solvency regardless of whether or not they are required to contribute. This is the view expressed by a member of the Wisconsin Manufacturers' Association who has made a careful study of unemployment compensation. He adds:4

"Experience has shown that there is never any difficulty in getting employees to understand that a fund contributed by their employers at a fixed percentage of payroll will not be able to stand unlimited drains, and that it is not fair to expect it to do so. But if the state contributes, there can be no acceptable excuse for shortages, and no amount of logical explanation can convince an employee that a fund to which he has been required, or even permitted, to contribute can with any justice be allowed to become inadequate to pay him full benefits in case he becomes unemployed."

British experience has been said to indicate a tendency on the part of workers to take the attitude that the mere fact that they have contributed to the insurance fund gives them a right to benefits and they therefore are inclined to get benefits if they can.

The statement that compulsory worker contributions are necessary in order to provide adequate benefits involves a judgment as to what is "adequate" and also as to the amount that employers may be required to contribute. When this argument was first advanced in the early stages of the campaign for unemployment compensation, bills requiring only employers to contribute fixed a 2 per cent contribution

\footnotetext{
' Roger Sherman Hoar in a letter to the New York Times, Sept. 12, 1934.
} 
rate. Advocates of employee contributions at that time urged that for the sake of adequacy the total should be made 3 per cent by compelling the workers to contribute an additional I per cent of wages. Subsequently, when legislation was introduced, and in some states enacted, requiring a 3 per cent contribution from employers alone-and with federal legislation enacted also levying a 3 per cent tax on employers-some of these advocates nevertheless continued their demand for worker contributions on the ground that no matter what the employers' contribution might be, an additional amount taken from the workers' pay-envelope would make the funds available for benefits "more adequate"! Opponents of employee contributions point out that a 4 or even 5 per cent contribution could be levied on employers without serious consequences, provided this rate was made uniform as between employers in competing states.

Under workmen's compensation legislation, America's first great step in social insurance, the principle is now firmly established that the cost of benefits for occupational injuries should be made a charge on industry and thus enter into the cost of production. It has been generally recognized that this feature of workmen's compensation has had a remarkably stimulating effect upon preventive effort by employers. In approaching the problem of unemployment-the only purely industrial hazard-there appears to be sound reason for applying the same principle. So long as the profit-motive continues to be the chief driving force in economic life, it will continue to be wise social policy wherever possible by such devices to harness this motive in the interest of the general welfare. A careful weighing of the arguments for and against compulsory worker contributions appear to tip the scales, both of justice and of expediency, in favor of making the entire direct cost of unemployment compensation an expense of doing business. 